\title{
Serum soluble urokinase plasminogen activator receptor (sUPAR) in adults with growth hormone deficiency
}

\author{
Charlotte Höybye ${ }^{1,2}$, Laia Faseh², Christos Himonakos ${ }^{2,3}$, Tomasz Pielak ${ }^{4}$ and Jesper Eugen-Olsen ${ }^{5}$ \\ ${ }^{1}$ Patient Area Endocrinology and Nephrology, Infection and Inflammation Theme, Karolinska University Hospital, Stockholm, Sweden \\ ${ }^{2}$ Department of Molecular Medicine and Surgery, Karolinska Institute, Stockholm, Sweden \\ ${ }^{3}$ Department of Medicine, Karlstad Hospital, Karlstad, Sweden \\ ${ }^{4}$ NUTOPI Sp. z o. o., Poznan, Poland \\ ${ }^{5}$ Clinical Research Centre, Copenhagen University Hospital Hvidovre, Hvidovre, Denmark
}

Correspondence should be addressed to C Höybye: charlotte.hoybye@sll.se

\begin{abstract}
Growth hormone deficiency (GHD) syndrome is associated with adverse levels of several risk factors for cardiovascular diseases (CVD), including metabolic inflammation. However, the impact of GHD and GH treatment on low-grade inflammation is unknown. The aim of the study was to establish the level of the low-grade inflammation biomarker soluble urokinase plasminogen activator receptor (sUPAR) in adults with GHD and the response to long-term GH treatment. Measurements of suPAR and CRP were performed in bio-bank serum samples from 72 adults, 34 males and 38 females, with GHD before and during at least 5 years of GH treatment. Mean age was $52.5 \pm 15.5$ years, BMI $27.3 \pm 5 \mathrm{~kg} / \mathrm{m}^{2}$. Clinical evaluations and blood sampling were performed at routine visits. Data on demography, anthropometry, lab results and clinical events were retrieved from post-marketing surveillance study databases and medical records. suPAR and high-sensitive (hs) CRP were analysed using ELISA and immunochemistry, respectively. At baseline blood pressure, lipid profile and fasting glucose were within the normal reference range. Baseline geometric mean and $95 \% \mathrm{Cl}$ of suPAR was 2.9 (2.7-3.3) $\mathrm{ng} / \mathrm{mL}$ and of CRP 2.3 (0.6-4.0) $\mathrm{mg} / \mathrm{L}$. Mean follow-up was $8 \pm 2$ years. The suPAR levels remained stable during follow-up, although individual increases were seen on occurrence or presence of co-morbidities. In contrast, levels of CRP decreased. In conclusion, the decrease in CRP and indirectly the absence of an expected increase in suPAR over time indicates a favourable effect of GH on low-grade inflammation.
\end{abstract}

Key Words

- growth hormone deficiency in adults

- growth hormone treatment

- low-grade inflammation

- suPAR

\section{Introduction}

The adult growth hormone (GH) deficiency (GHD) syndrome includes unfavourable levels of several wellknown risk factors for cardiovascular disease (CVD), such as adverse body composition, cholesterol levels and inflammatory markers (1, 2, 3, 4, 5, 6). In accordance, previous epidemiological studies found an increased mortality in GHD, particularly for CVD $(7,8,9)$. However, this was less clear from more recent studies $(10,11)$.
Numerous studies have shown that GH treatment improves the above-mentioned risk factors for CVD $(1,2$, $3,5,6,7,12,13,14)$, but it is currently unknown if GHD and long-term GHD treatment influences the level of lowgrade inflammation.

Urokinase plasminogen activator receptor (uPAR) is a membrane bound receptor mainly expressed on immune cells $(15,16)$. uPAR is involved in several physiological

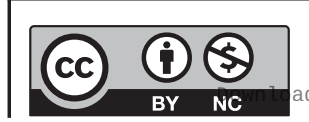

This work is licensed under a Creative Commons Attribution-NonCommercial 4.0 International License. ded from Bioscientifica.com at 04/26/2023 02:46:01AM 
and pathological pathways including cell signalling, cell migration, immune response, angiogenesis and fibrinolysis $(15,16)$. Binding of UPA to UPAR facilitates cleavage and generation of soluble UPAR (suPAR). suPAR positively correlates to the activation of the inflammatory and immune systems and is present in blood, urine and cerebrospinal fluid $(15,16)$. Elevated levels of suPAR have been associated with poor clinical outcomes of a number of infectious diseases and cancers $(17,18,19,20,21,22)$. Furthermore, suPAR has also been shown to be prognostic for development of cancer, CVD and type 2 diabetes as well as mortality in the general population $(23,24)$. Finally, suPAR has been shown to be a marker for development of renal insufficiency (25). suPAR is anticipated to reflect inflammation on the cellular level (24).

The impact of GHD and GH treatment on low-grade inflammation and the level of suPAR in patients with GHD are unknown. The primary aim of this study was to establish baseline suPAR levels in a cohort of adults with GHD. The secondary aims were to measure suPAR during long-term GH treatment and clinical events.

\section{Materials and methods}

The study was approved by the Ethical Committee in Stockholm (Dnr 2016/169-3), and no study-related activity was performed before achievement of the patients' consent.

In patients with confirmed GHD treated with GH during 1995-2010 serum was sampled for bio-bank storage at the patient's routine visits to the clinic. Based on availability of bio-bank samples for at least 5 years of GH treatment, a cohort of 72 patients with GHD was identified.

Twenty-nine patients had previously been treated for non-functioning pituitary adenomas (NFPA); four patients for $\mathrm{GH}$ producing adenoma, five patients for ACTH producing adenoma, seven for prolactinoma, four patients for craniopharyngeoma and 23 for other diseases in the area (meningioma $(N=7)$, idiopathic hypopituitarism $(N=6)$, hypophysitis $(N=3)$, empty sella $(N=3)$, opticus glioma $(N=2)$, Ratkes cyst $(N=1)$, traumatic brain injury $(N=1))$. The patients had been treated with pituitary surgery, fractionated radiotherapy, Gamma knife radiosurgery and pharmacological treatments and they were all cured or in remission for their pituitary disease.

Nine patients had no other pituitary deficiencies than GHD, 19 had one pituitary deficiency in addition to GHD, 11 had two additional deficiencies, 31 had three additional deficiencies and 2 had four additional deficiencies. Replacements for other pituitary deficiencies than GHD were stable since many years.

Thirteen patients received treatment for hypertension, three for hypercholesterolemia and two for diabetes mellitus type 2. Two patients had chronic ischaemic heart disease and one patient previously had an acute myocardial infarction. All but one patient had normal kidney function. Several patients were on pain-relieving and anti-depressive medication.

All patients had confirmed GHD according to consensus guidelines. The patients were treated once daily with subcutaneous injection of $\mathrm{GH}$ at bedtime. Doses were individually titrated to insulin-like growth factor I (IGF-I) levels in age-matched healthy subjects. Clinical examinations and sampling of fasting routine blood tests were performed at scheduled visits to the clinic and in addition $2 \mathrm{~mL}$ serum was stored in a bio-bank (at $-70^{\circ} \mathrm{C}$ ).

The patients were enrolled in two post-marketing observational databases of GH treatment in adults with GHD, NordiNet (NovoNordisk) and KIMS (Pfizer). Data on demography (age at baseline, gender, smoking), weight, BMI, waist circumference, waist/hip ratio, blood pressure, fasting blood glucose, HbA1C, total, LDL and HDL cholesterol, triglycerides, IGF-I, concomitant medication, clinical events and co-morbidities were retrieved from the databases and the patients' medical records at baseline and during GH treatment.

In serum samples from the bio-bank two markers for low-grade inflammation, suPAR and high-sensitive C-reactive protein (hsCRP), were analysed before and after approximately 1, 3, 6 and 12 months of GH treatment and thereafter once yearly.

For a more detailed evaluation the cohort was divided into three groups; one group of patients who did not develop CVD (cerebral infarction, ischaemic heart disease) or tumours (benign and malign) during follow-up $(N=57)$, one group who developed CVD $(N=8)$ and one group who developed tumours $(N=7)$.

\section{Anthropometric methods}

Physical examination included measurements of height, weight, waist and hip. Waist and hip were measured in standing position. Waist circumference was measured halfway between the costal edge and iliac crest and cutoff points for obesity were set to $88 \mathrm{~cm}$ in female and $102 \mathrm{~cm}$ in male patients. Hip was measured at the greatest circumference and waist-to-hip (WH) ratio above 0.85 in female and 1.0 in male patients defined obesity. 
BMI was calculated as weight divided by the square height, $\mathrm{kg} / \mathrm{m}^{2}$. BMI from 18.5 to $25 \mathrm{~kg} / \mathrm{m}^{2}$ was defined as normal, between 25 and $30 \mathrm{~kg} / \mathrm{m}^{2}$ as overweight and above $30 \mathrm{~kg} / \mathrm{m}^{2}$ as obese according to WHO criteria.

\section{Assays}

Fasting blood glucose was determined by the glucose oxidase method using a standard glucose analyzer (YSI, Inc., Yellow Springs, OH, USA). Normal fasting blood glucose $<6.1 \mathrm{mmol} / \mathrm{L}$. $\mathrm{HbA}_{1 \mathrm{C}}$ was analysed using the Mono-S method and IFCC, normal HbA1C $<42 \mathrm{mmol} / \mathrm{L}$. Results from the Mono-S method were converted to $\mathrm{mmol} / \mathrm{mol}$.

Serum cholesterol and triglycerides were measured with colorimetric methods (Vitos 900) and high-density lipoprotein (HDL) with direct calorimetry (Hitachi 911). LDL cholesterol concentration was calculated according to Friedewald's formula. Serum IGF-I levels were measured using a solid-phase, enzyme-labelled chemiluminescent immunometric assay (IMMULITE 2000, Siemens). Age- and gender-specific reference ranges were used to determine IGF-I SDS.

Serum (S) suPAR was analysed using a commercial suPARnostic ELISA assay (ViroGates, Copenhagen, Denmark). All samples were analysed for S-suPAR at the same time and in the same batch with an interassay coefficient of variation of $9.9 \%$. S-suPAR has been shown to be stable in frozen samples, also after long-term storage. Based on previously reported S-suPAR levels (24), we set $\mathrm{S}$-suPAR $<3 \mathrm{ng} / \mathrm{mL}$ in both genders as normal and $>4.0 \mathrm{ng} / \mathrm{mL}$ as high risk for other diseases, including CVD and development of tumours.

Serum hsCRP was analysed with immunochemistry, Cobas 8000, Roche Diagnostics. Normal levels $<3$ mg/L.

\section{Statistical analysis}

Baseline demographics, height and weight, BMI, waist, hip, waist/hip ratio, blood pressure and lab-data are presented as mean \pm s.D., except suPAR and CRP which are presented as geometric mean and 95\% CI. Clinical events and co-morbidities were summarised but not statistically evaluated. Data were non-normally distributed and non-parametric tests (Mann-Whitney and Kruskal-Wallis tests) were used for statistical analyses within and between groups. Correlations at baseline were calculated between suPAR levels and all other variables by using Spearman's correlation test. Significance value was set at $P<0.05$.

\section{Results}

\section{Baseline}

\section{Total cohort}

Gender distribution was similar: 34 (47\%) male patients and 38 (53\%) female patients. Ten patients were smoking. Mean age was $52.5 \pm 15.5$ years. IGF-I standard deviation score (SDS) was $-1.99 \pm 0.24$. Baseline anthropometric and biomarker measurements are shown in Table 1 . In addition, waist circumference was $96.5 \pm 12 \mathrm{~cm}$, waist/hip ratio $0.93 \pm 0.06$, fasting glucose $4.6 \pm 0.9 \mathrm{mmol} / \mathrm{L}$, total cholesterol $5.4 \pm 1.1 \mathrm{mmol} / \mathrm{L}$, high-density lipoprotein (HDL) cholesterol $1.3 \pm 0.4 \mathrm{mmol} / \mathrm{L}$ and triglyceride $1.7 \pm 1.1 \mathrm{mmol} / \mathrm{L}$.

At baseline geometric mean suPAR in the total cohort was $2.9 \mathrm{ng} / \mathrm{mL}(2.7-3.3)$, $>3 \mathrm{ng} / \mathrm{mL}$ in 28 patients, $>4 \mathrm{ng} / \mathrm{mL}$ in 14 patients and $>5 \mathrm{ng} / \mathrm{mL}$ in 4 patients. Out of these four patients one patient with small-vessel vasculitis had a level of $6.2 \mathrm{ng} / \mathrm{mL}$, one patient with chronic ischaemic heart disease had a level of $5.9 \mathrm{ng} / \mathrm{mL}$, one patient with tonsillitis had a level of $6.7 \mathrm{ng} / \mathrm{mL}$ and one patient with renal insufficiency had a level of $5.4 \mathrm{ng} / \mathrm{mL}$. Among the other 24 patients with suPAR $>3.0 \mathrm{ng} / \mathrm{mL}$, six patients had

Table 1 Baseline characteristics of 72 patients with growth hormone deficiency (GHD).

\begin{tabular}{lc}
\hline Baseline characteristics $(N=72)$ & Mean \pm s.o. \\
\hline Age (years) & $52.5 \pm 15.5$ \\
Blood pressure $(\mathrm{mmHg})$ & $132 / 82 \pm 19 / 8$ \\
Weight $(\mathrm{kg})$ & $79.9 \pm 15.5$ \\
BMI (kg/m $\left.{ }^{2}\right)$ & \\
$\quad$ Females & $27.0 \pm 4.9$ \\
$\quad$ Males & $27.5 \pm 5.1$ \\
Waist circumference (cm) & \\
$\quad$ Females & $93 \pm 12$ \\
$\quad$ Males & $100 \pm 11$ \\
Hip/waist ratio & \\
$\quad$ Females & $0.88 \pm 0.06$ \\
$\quad$ Males & $0.97 \pm 0.06$ \\
IGF-I-SDS & \\
$\quad$ Females & $-1.96 \pm 0.24$ \\
$\quad$ Males & $-2.02 \pm 0.23$ \\
Fasting blood glucose (mmol/L) & $4.6 \pm 0.9$ \\
HbA1c (mmol/mol) & $34.4 \pm 8.5$ \\
Total cholesterol (mmol/L) & $5.4 \pm 1.1$ \\
LDL cholesterol (mmol/L) & $3.4 \pm 0.9$ \\
HDL cholesterol (mmol/L) & $1.3 \pm 0.4$ \\
Triglycerides (mmol/L) & $1.7 \pm 1.1$ \\
SUPAR (ng/mL) (geometric mean, Cl) & $2.9(2.7-3.3)$ \\
CRP (mg/L) (geometric mean, Cl) & $2.3(0.6-4.0)$ \\
\hline
\end{tabular}

$\mathrm{BMI}$, body mass index; CRP, high-sensitivity CRP; HbA1C, haemoglobin A1 c; HDL, high-density lipoprotein; IGF-I, insulin like growth factor I; LDL, low density lipoprotein; suPAR, soluble urokinase plasminogen activator receptor. 
hypertension and hypercholesterolemia, three patients with various inflammatory diseases, while no particular co-morbidity could be identified in 15 patients.

The geometric mean for CRP was $2.3 \mathrm{mg} / \mathrm{L}(0.6-4.0)$, and was $>3 \mathrm{mg} / \mathrm{L}$ in 18 patients.

No correlations between suPAR and the variables displayed in Table 1 were seen, except for CRP $(P=0.01)$. No gender or age differences in baseline data were observed (data not shown). Correlation between suPAR and IGF-I was not significant $(P=0.15)$.

\section{Sub-group analyses}

Baseline data for the three subgroups are displayed in Table 2. The groups did not differ in age, BMI, blood pressure, HbA1C, LDL cholesterol or suPAR levels. On the other hand, CRP was higher in patients who developed CVD. Three out of the eight patients who developed CVD had baseline suPAR $>3 \mathrm{ng} / \mathrm{mL}$, four out of the seven patients who developed tumours had baseline suPAR $>3 \mathrm{ng} / \mathrm{mL}$.

\section{GH treatment period}

\section{Total cohort}

The mean duration of follow-up during GH treatment was $8 \pm 2$ years. GH treatment generated an increase in IGF-I and blood glucose ( $P=0.001$ and $P=0.003$ respectively). No other changes were observed except for a decrease in LDL cholesterol in female patients $(P=0.002)$, which was also the only gender difference found. No change in suPAR was observed during GH treatment ( $P=0.36$, Fig. 1 ). There was no correlation between IGF-I and suPAR at one or 5 years of GH treatment (data not shown). In contrast, CRP decreased during follow-up $(P=0.018)$.

Several clinical events happened during the GH treatment period; however, most of them outside the

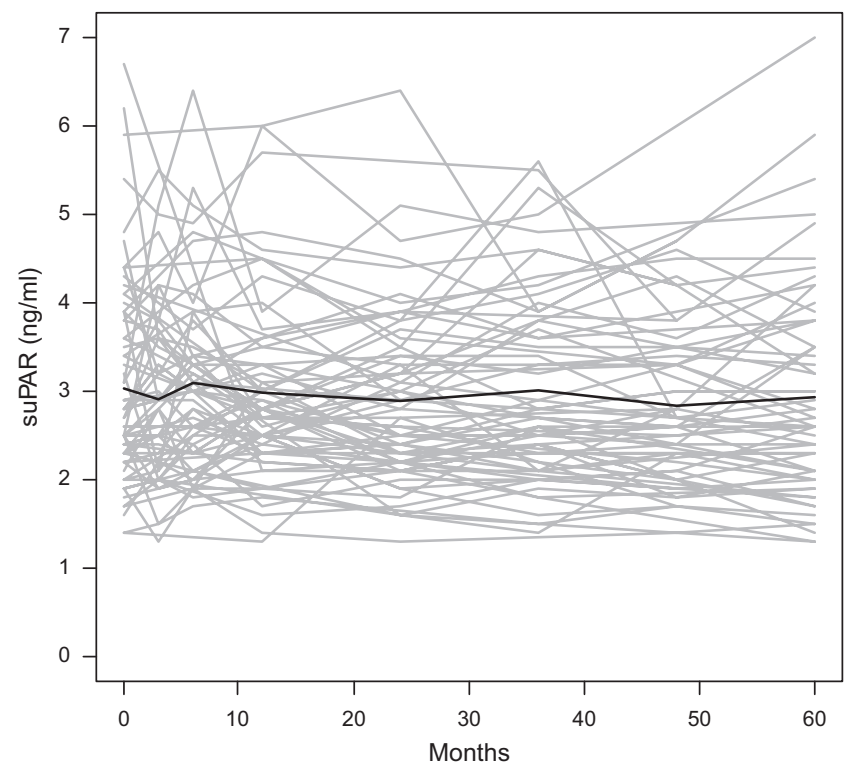

Figure 1

Individual levels of soluble urokinase plasminogen activator receptor (suPAR) in 72 adults with growth hormone (GH) deficiency during long-term GH treatment. The bold line shows median suPAR.

scheduled visits and most were not severe. The most frequently reported events were various unspecific muscular-skeletal problems which were reported 18 times. Upper airway infections were reported 13 times and problems from the gastrointestinal tract were reported 16 times, problems from the lower respiratory tract were reported 7 times. One patient had cerebral infarction, one TIA (transient ischaemic attack), two had acute myocardial infarction, two developed cardiac insufficiency, one developed angina pectoris and one patient AV block 3. These eight events happened beyond 5 years of GH treatment. Another three patients had re-growth of their pituitary tumour, two developed meningioma, one developed myelofibrosis and one lung cancer.

Table 2 Baseline characteristics (mean \pm s.D.) in 72 adults with growth hormone deficiency (GHD) divided in patients who did not develop cardiovascular disease (CVD) or tumours, patients who developed CVD and patients who developed tumours during a mean of 8 years $\mathrm{GH}$ treatment.

\begin{tabular}{lcc}
\hline & No development of CVD or tumours $(N=57)$ \\
\cline { 1 - 1 } Age (years) & $51.7 \pm 15.5$ \\
Gender $($ female/male) & $29 / 28$ \\
BMI $\left(\mathrm{kg} / \mathrm{m}^{2}\right)$ & $27.1 \pm 4.5$ \\
Blood pressure $(\mathrm{mmHg})$ & $130 / 82 \pm 18 / 9$ \\
HbA1C & $34.9 \pm 8.6$ \\
LDL cholesterol & $3.5 \pm 0.9$ \\
\hline
\end{tabular}

\begin{tabular}{c}
\hline Development of CVD $(N=8)$ \\
\hline $58.0 \pm 14.7$ \\
$4 / 4$ \\
$26.3 \pm 4.7$ \\
$142 / 83 \pm 17 / 8$ \\
$36.6 \pm 7.4$ \\
$3.1 \pm 0.7$
\end{tabular}

Development of tumours $(N=7)$

$57.9 \pm 13.9$

$5 / 2$

$29.5 \pm 8.6$

$134 / 78 \pm 28 / 7$

$30.6 \pm 8.7$

$3.3 \pm 1.2$

There were no differences between groups.

BMI, body mass index; CVD, cardiovascular disease; HbA1c, haemoglobin A1c; LDL, low density lipoprotein.

https://ec.bioscientifica.com

https://doi.org/10.1530/EC-19-0159 (c) 2019 The authors Published by Bioscientifica Ltd

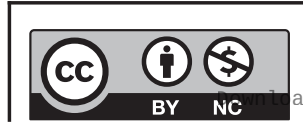

This work is licensed under a Creative Commons Attribution-NonCommercial 4.0 International License. ded from Bioscientifica.com at 04/26/2023 02:46:01AM 


\section{Sub-group analyses}

BMI, blood pressure, HbA1C and LDL cholesterol did not differ within or between the three groups at 1 and 5 years of GH treatment (data not shown). suPAR was also unchanged within and between the three subgroups at 1 or 5 years of GH treatment (Table 3), but a nonsignificant increase over time was noted in patients who developed tumours. CRP decreased in patients who did not develop CVD or tumours $(P=0.043)$, while it was unchanged in patients who developed CVD $(P=0.677)$ or tumours $(P=0.685)$.

\section{suPAR is a stable biomarker over time}

To test the stability of suPAR over time, we carried out a correlation analysis of baseline and 5-year suPAR (Fig. 2). Pearson correlation analysis showed a coefficient of $0.63(\mathrm{CI}=0.45-0.76, P<0.001)$. With regard to CRP, baseline and 5-year CRP measurements were available in 59 patients. The correlation coefficient was 0.19 , which was not significant.

\section{Discussion}

In this study of 72 patients with GHD, GH treatment led to an increase in IGF-I, in blood glucose and in female patients a decrease in LDL cholesterol. The lowgrade inflammatory biomarker suPAR did not change during long-term GH treatment, whereas a decrease was seen in CRP. Individual increases in suPAR were seen on occurrence or presence of co-morbidities, but no differences were observed between the eight patients who developed CVD, the seven patients who developed tumours or the 57 patients who did not develop these diseases. On the other hand, a decrease in CRP was

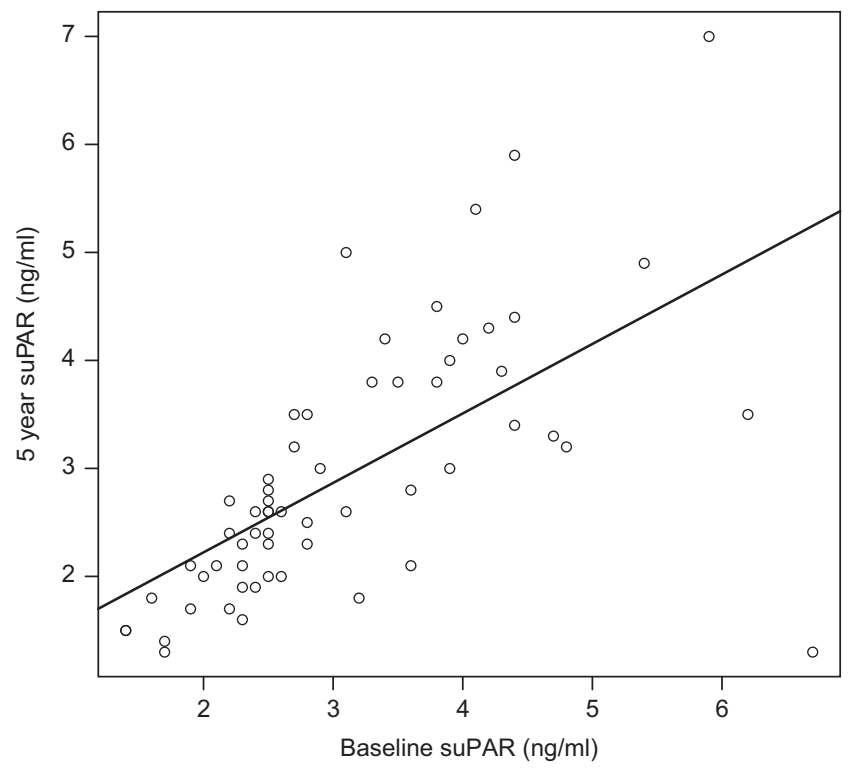

Figure 2

Correlation between baseline and 5-year soluble urokinase plasminogen activator receptor (suPAR) measurements in 72 adults with growth hormone $(\mathrm{GH})$ deficiency.

seen in the group of patients who did not develop CVD or tumours.

It is well documented that GH replacement in adults with GHD improves body composition by increasing muscle mass and reducing body fat, in particular, the abdominal and visceral fat $(1,2,3,5,7,12,13,14,26)$. At baseline our patients were overweight and no changes in anthropometric variables were observed during GH treatment. Similar to other studies we found no associations between suPAR and anthropometric variables probably because the patients were not severely obese (24). This supports the previous statement that suPAR reflects inflammation on the cellular level and CRP metabolic inflammation (24). In contrast to previous

Table 3 Serum (S) soluble urokinase plasminogen activator receptor (suPAR) and high-sensitivity CRP (geometric mean and 95\% confidence interval) at baseline, 1 year and 5 years of growth hormone (GH) treatment in 72 adults with GH deficiency (GHD) divided in patients who did not develop cardiovascular disease (CVD) or tumours, patients who developed CVD and patients who developed tumours during a mean of 8 years GH treatment.

\begin{tabular}{|c|c|}
\hline & No development of CVD or tumours $(N=57)$ \\
\hline Baseline suPAR & $2.8(2.7-3.3)$ \\
\hline 1 year suPAR & $2.7(2.5-3.1)$ \\
\hline 5 years SUPAR & $2.6(2.5-3.1)$ \\
\hline Baseline CRP & $2.3(2.4-5.7)$ \\
\hline 1 year CRP & $1.4(1.2-3.4)$ \\
\hline 5 years CRP & $1.0(1.0-2.2)$ \\
\hline
\end{tabular}

\begin{tabular}{l} 
Development of CVD $(N=8)$ \\
\hline $3.0(2.2-4.2)$ \\
$3.0(2.6-4.0)$ \\
$3.0(2.5-3.9)$ \\
$4.5(1.8-10.4)$ \\
$4.1(-9.3$ to 31.7$)$ \\
$7.2(-4.0$ to 27.2$)$ \\
\hline
\end{tabular}

Development of tumours $(N=7)$

$3.2(2.7-3.9)$

$3.1(2.6-4.0)$

$3.4(2.9-4.3)$

$2.3(0.4-6.4)$

$1.9(0.2-5.2)$

$1.7(-3.8$ to 14.0$)$

No significant changes were seen for suPAR over time from baseline to 5 years of GH treatment in any of the groups. A significant increase in CRP was seen in the group who developed CVD $(P=0.043)$, whereas no changes were seen in the other two groups.

https://ec.bioscientifica.com https://doi.org/10.1530/EC-19-0159 (c) 2019 The authors Published by Bioscientifica Ltd

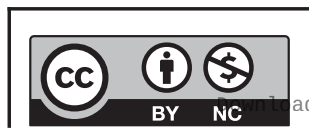

This work is licensed under a Creative Commons Attribution-NonCommercial 4.0 International License. ded from Bioscientifica.com at 04/26/2023 02:46:01AM via free access 
observations (24), we did not find a positive correlation between age and suPAR level probably because of the heterogeneity of our study population.

Adults with GHD often have impaired glucose tolerance or diabetes type 2, usually attributed to the concomitant visceral adiposity, and conflicting results with both an increase and a decrease have been reported during $\mathrm{GH}$ treatment $(12,26,27)$. At baseline, glucose levels as well as HbA1C were within the normal range for healthy individuals and as expected we observed an increase in blood glucose within normal range during GH treatment. Two patients already had diabetes at baseline, but none of the other patients developed diabetes during GH treatment. No association between suPAR and glucose or HbA1C was observed.

In GHD, elevated total cholesterol has been reported in both genders as well as increased concentrations of LDL cholesterol and triglycerides $(3,4,27)$. GH treatment has beneficial effects on circulating lipids, for a decrease in total and LDL cholesterol, while changes in HDL and triglycerides are inconsistent (27). In our cohort baseline lipid profile was within the normal reference for healthy individuals and did not change during GH treatment, although the expected decrease in LDL cholesterol was seen in female patients. Throughout the study, blood pressure was normal, including patients on antihypertensive treatment. We did not find an association between suPAR and lipid profile or blood pressure.

In patients with GHD some studies have shown elevation of the inflammatory markers CRP, IL-6 and TNF-alpha $(28,29,30,31)$, which are markers associated with an increased risk of CVD in the general population. The reported effects of GH treatment on these inflammatory markers have varied in previous reports. In line with some studies, we observed a reduction in CRP $(6,28)$; however, this was not reported in another study (30). In other studies, no effect on IL- 6 during GH treatment was noticed $(6,28)$, whereas a decrease was reported in another (30).

suPAR increases during progression of several diseases and decreases during improvement but is sustained at an elevated level longer than CRP (32). Multiple studies in different patient populations have shown that elevated levels of suPAR are associated with increased morbidity and mortality. Furthermore, it has recently been shown that treatment with low-dose GH in patients with HIV non-significantly decreased suPAR levels (33). In the present cohort, mean suPAR did not change as a result of initiation of GH treatment and did not change during more than 5 years of GH treatment. This could be interpreted as a beneficial effect of GH treatment as an agerelated in suPAR over 5 years would have been expected $(24,34)$. However, due to lack of controls in the current study, further studies comparing GHD patients on GH treatment to healthy controls is needed to confirm this potential effect. A rise in suPAR levels was documented in patients where blood was sampled in close proximity to clinical events. Some patients with chronic co-morbidities also displayed higher suPAR levels. At 1 and 5 years of GH treatment we did not observe any differences in suPAR or CRP levels between patients who did and did not develop CVD. The pharmacological treatment of hypertension, diabetes and hypercholesterolemia might indirectly have inhibited progression of inflammation and reduced the total risk for CVD. In the group of patients who developed tumours suPAR albeit non-significantly increased but the number of patients was too small to make firm conclusions in line with previous observations. Another explanation could be that only two patients developed cancers, while the others developed benign tumours which might have a weaker effect on suPAR.

The strength of this study is the long follow-up and careful prospective sampling of serum during $\mathrm{GH}$ treatment. A control group was not established as the serum samples were collected many years ago and only from patients with GHD, which made it difficult to identify a proper control group as of today. In some other published studies, results were reported in plasma samples where suPAR levels are lower which made direct comparison difficult. Another limitation of the study is that the bio-bank serum was sampled at routine, scheduled visits to the clinic and not sampled when a clinical event actually occurred. Also, patients were included based on availability of serum samples for at least 5 years of GH treatment, which probably selected a cohort of healthier and compliant survivors. Moreover, it is a limitation that the age range was wide and that only few patients developed CVD and tumours. In experimental studies, it has been reported that activation of plasminogen to plasmin by uPA may dissociate IGF-I from IGFBP complexes (35), and it can be speculated if measurement of free IGF-I and IGF-binding protein 3 (IGF-BP3) could have led to different results. However, in the clinical situation, IGF-I is the best marker to reflect GH's effect in various tissues (36) and measurements of free/bioactive IGF-I or IGF-binding proteins of limited clinical value. Furthermore, anthropometry and metabolic measures remained stable and the patients were their own controls and measurements of free IGF-I and IGFBP3 would not be expected to impact the results. 
In summary, no changes in suPAR levels were observed during long-term $\mathrm{GH}$ treatment. Increased suPAR levels were associated with occurrence or presence of co-morbidities, but routine measurements were not higher in patients who developed CVD or tumours. In addition, CRP decreased over time. Altogether, our results suggest favourable effects of GH treatment on low-grade inflammation.

\section{Declaration of interest}

$\mathrm{CH}$ is a senior editor for Endocrine Connections. She was not involved in the editorial process for this manuscript, on which she is listed as an author. $\mathrm{CH}$ : investigator and has received lecture fees for Novo Nordisk and Pfizer, Sweden. The other authors have nothing to disclose.

\section{Funding}

This research did not receive any specific grant from any funding agency in the public, commercial or not-for-profit sector.

\section{References}

1 Carroll PV, Christ ER, Bengtsson BA, Carlsson L, Christiansen JS Clemmons D, Hintz R, Ho K, Laron Z, Sizonenko P, et al. Growth hormone deficiency in adulthood and the effects of growth hormone replacement: a review. Growth Hormone Research Society Scientific Committee. Journal of Clinical Endocrinology and Metabolism $1998 \mathbf{8 3}$ 382-395. (https://doi.org/10.1210/jcem.83.2.4594)

2 Molitch ME, Clemmons DR, Malozowski S, Merriam GR, Vance ML $\&$ Endocrine Society. Evaluation and treatment of adult growth hormone deficiency: an Endocrine Society clinical practice guideline. Journal of Clinical Endocrinology and Metabolism 201196 1587-1609. (https://doi.org/10.1210/jc.2011-0179)

3 Gazzaruso C, Gola M, Karamouzis I, Giubbini R \& Giustina A. Cardiovascular risk in adult patients with growth hormone $(\mathrm{GH})$ deficiency and following substitution with GH-an update. Journal of Clinical Endocrinology and Metabolism 201499 18-29. (https://doi. org/10.1210/jc.2013-2394)

4 Abdu TA, Neary R, Elhadd TA, Akber M \& Clayton RN. Coronary risk in growth hormone deficient hypopituitary adults: increased predicted risk is due largely to lipid profile abnormalities. Clinical Endocrinology 200155 209-216. (https://doi.org/10.1046/j.13652265.2001.01320.x)

5 Appelman-Dijkstra NM, Claessen KMJA, Roelfsema F, Pereira AM \& Biermasz NR. Long-term effects of recombinant human GH replacement in adults with GH deficiency: a systematic review. European Journal of Endocrinology 2013169 R1-R14. (https://doi. org/10.1530/EJE-12-1088)

6 Deepak D, Daousi C, Javadpour M, Clark D, Perry Y, Pinkney J \& Macfarlane IA. The influence of growth hormone replacement on peripheral inflammatory and cardiovascular risk markers in adults with severe growth hormone deficiency. Growth Hormone and IGF Research 201020 220-225. (https://doi.org/10.1016/j. ghir.2010.02.002)

7 Rosen T \& Bengtsson BA. Premature mortality due to cardiovascular disease in hypopituitarism. Lancet 1990336 285-288. (https://doi. org/10.1016/0140-6736(90)91812-O)

8 Bates AS, Van't Hoff W, Jones PJ \& Clayton RN. The effect of hypopituitarism on life expectancy. Journal of Clinical Endocrinology and Metabolism 199681 1169-1172. (https://doi.org/10.1210/ jcem.81.3.8772595)

9 Bulow B, Hagmar L, Mikoczy Z, Nordstrom CH \& Erfurth EM. Increased cerebrovascular mortality in patients with hypopituitarism. Clinical Endocrinology 199746 75-81. (https://doi. org/10.1046/j.1365-2265.1997.d01-1749.x)

10 Stochholm K, Laursen T, Green A, Laurberg P, Andersen M, Kristensen LØ, Feldt-Rasmussen U, Christiansen JS, Frydenberg M \& Gravholt CH. Morbidity and GH deficiency: a nationwide study. European Journal of Endocrinology 2008158 447-457. (https://doi. org/10.1530/EJE-07-0523)

11 Erfurth EM. Update in mortality in GH-treated patients. Journal of Clinical Endocrinology and Metabolism 201398 4219-4226. (https:// doi.org/10.1210/jc.2013-2415)

12 Weber MM, Biller BM, Pedersen BT, Pournara E, Christiansen JS \& Höybye C. The effect of growth hormone $(\mathrm{GH})$ replacement on blood glucose homeostasis in adult nondiabetic patients with GH deficiency: real-life data from the NordiNet@ International Outcome Study. Clinical Endocrinology 201686 192-198. (https://doi. org/10.1111/cen.13256)

13 Jørgensen AP, Fougner KJ, Ueland T, Gudmundsen O, Burman P, Schreiner T \& Bollerslev J. Favorable long-term effects of growth hormone replacement therapy on quality of life, bone metabolism, body composition and lipid levels in patients with adult-onset growth hormone deficiency. Growth Hormone and IGF Research 2011 21 69-75. (https://doi.org/10.1016/j.ghir.2011.01.001)

14 Elbornsson M, Götherström G, Bosæus I, Bengtsson BÅ, Johannsson G \& Svensson J. Fifteen years of GH replacement improves body composition and cardiovascular risk factors. European Journal of Endocrinology 2013168 745-753. (https://doi.org/10.1530/ EJE-12-1083)

15 Blasi F \& Carmeliet P. uPAR: a versatile signaling orchestrator. Nature Reviews: Molecular Cell Biology 20023 932-943. (https://doi. org/10.1038/nrm977)

16 Madsen CD, Ferraris GM, Andolfo A, Cunningham O \& Sidenius N. uPAR-induced cell adhesion and migration: vitronectin provides the key. Journal of Cell Biology 2007177 927-939. (https://doi. org/10.1083/jcb.200612058)

17 Sidenius N, Sier CF, Ullum H, Pedersen BK, Lepri AC, Blasi F \& EugenOlsen J. Serum level of soluble urokinase-type plasminogen activator receptor is a strong and independent predictor of survival in human immunodeficiency virus infection. Blood 200096 4091-4095.

18 Kofoed K, Eugen-Olsen J, Petersen J, Larsen K \& Andersen O. Predicting mortality in patients with systemic inflammatory response syndrome: an evaluation of two prognostic models, two soluble receptors, and a macrophage migration inhibitory factor. European Journal of Clinical Microbiology and Infectious Diseases 200827 375-383. (https://doi.org/10.1007/s10096-007-0447-5)

19 Rabna P, Andersen A, Wejse C, Oliveira I, Gomes VF, Haaland MB Aaby P \& Eugen-Olsen J. High mortality risk among individuals assumed to be TB-negative can be predicted using a simple test. Tropical Medicine and International Health 200914 986-994. (https:// doi.org/10.1111/j.1365-3156.2009.02328.x)

20 Ostrowski SR, Ullum H, Goka BQ, Høyer-Hansen G, Obeng-Adjei G, Pedersen BK, Akanmori BD \& Kurtzhals JA. Plasma concentrations of soluble urokinase-type plasminogen activator receptor are increased in patients with malaria and are associated with a poor clinical or a fatal outcome. Journal of Infectious Diseases 2005191 1331-1341. (https://doi.org/10.1086/428854)

21 Mustjoki S, Sidenius N, Sier CF, Blasi F, Elonen E, Alitalo R \& Vaheri A. Soluble urokinase receptor levels correlate with number of circulating tumor cells in acute myeloid leukemia and decrease rapidly during chemotherapy. Cancer Research 200060 7126-7132.

22 deBock CE \& Wang Y. Clinical significance of urokinase-type plasminogen activator receptor (uPAR) expression in cancer. https://ec.bioscientifica.com https://doi.org/10.1530/EC-19-0159 (c) 2019 The authors Published by Bioscientifica Ltd

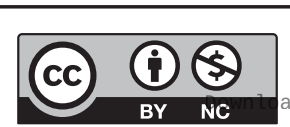

This work is licensed under a Creative Commons Attribution-NonCommercial 4.0 International License. ded from Bioscientifica.com at 04/26/2023 02:46:01AM 
Medicinal Research Reviews 200424 13-39. (https://doi.org/10.1002/ med.10054)

23 Eugen-Olsen J, Andersen O, Linneberg A, Ladelund S, Hansen TW, Langkilde A, Petersen J, Pielak T, Moller LN, Jeppesen J, et al. Circulating soluble urokinase plasminogen activator receptor predicts cancer, cardiovascular disease, diabetes and mortality in the general population. Journal of Internal Medicine 2010268 296-308. (https:// doi.org/10.1111/j.1365-2796.2010.02252.x)

24 Haupt TH, Kallemose T, Ladelund S, Rasmussen LJ, Thorball CW, Andersen O, Pisinger C \& Eugen-Olsen J. Risk factors associated with serum levels of the inflammatory biomarker soluble urokinase plasminogen activator receptor in a general population. Biomarker Insights 20149 91-100. (https://doi.org/10.4137/BMI.S19876)

25 Hayek SS, Sever S, Ko YA, Trachtman H, Awad M, Wadhwani S, Atlintas MM, Wei C, Hotton AL, French AL, et al. Soluble urokinase receptor and chronic kidney disease. New England Journal of Medicine 2015373 1916-1925. (https://doi.org/10.1056/ NEJMoa1506362)

26 Stochholm K \& Johannsson G. Reviewing the safety of GH replacement therapy in adults. Growth Hormone and IGF Research 201525 149-157. (https://doi.org/10.1016/j.ghir.2015.06.006)

27 Höybye C \& Christiansen JS. Growth hormone replacement in adults - current standards and new perspectives. Best Practice and Research: Clinical Endocrinology and Metabolism 201529 115-123. (https://doi. org/10.1016/j.beem.2014.09.006)

28 Andreassen M, Vestergaard H \& Kristensen LØ. Concentrations of the acute phase reactants high-sensitive C-reactive protein and YKL-40 and of interleukin- 6 before and after treatment in patients with acromegaly and growth hormone deficiency. Clinical Endocrinology 200767 909-916. (https://doi.org/10.1111/j.13652265.2007.02986.x)

29 Leonsson M, Hulthe J, Johannsson G, Wiklund O, Wikstrand J, Bengtsson BA \& Oscarsson J. Increased interleukin-6 levels in pituitary-deficient patients are independently related to their carotid intima-media thickness. Clinical Endocrinology 200359 242-250. (https://doi.org/10.1046/j.1365-2265.2003.01832.x)

30 Sesmilo G, Biller BM, Llevadot J, Hayden D, Hanson G, Rifai N \& Klibanski A. Effects of growth hormone administration on inflammatory and other cardiovascular risk markers in men with growth hormone deficiency. A randomized, controlled clinical trial. Annals of Internal Medicine 2000133 111-122. (https://doi. org/10.7326/0003-4819-133-2-200007180-00010)

31 Sesmilo G, Miller KK, Hayden D \& Klibanski A. Inflammatory cardiovascular risk markers in women with hypopituitarism. Journal of Clinical Endocrinology and Metabolism 200186 5774-5781. (https:// doi.org/10.1210/jcem.86.12.8087)

32 Lyngbæk S, Sehestedt T, Marott JL, Hansen TW, Olsen MH, Andersen O, Linneberg A, Madsbad S, Haugaard SB, Eugen-Olsen J, et al. CRP and suPAR are differently related to anthropometry and subclinical organ damage. International Journal of Cardiology $2013 \mathbf{1 6 7}$ 781-785. (https://doi.org/10.1016/j.ijcard.2012.03.040)

33 Bjerre Lindboe JB, Langkilde A, Eugen-Olsen J, Hansen BR, Haupt TH, Petersen J \& Andersen O. Low-dose growth hormone therapy reduces inflammation in HIV-infected patients: a randomized placebocontrolled study. Infectious Diseases 201648 829-837. (https://doi.org /10.1080/23744235.2016.1201722)

34 Haupt TH, Rasmussen LJH, Kallemose T, Ladelund S, Andersen O, Pisinger C \& Eugen-Olsen J. Healthy lifestyles reduce suPAR and mortality in a Danish general population study. Immunity and Ageing 201916 1. (https://doi.org/10.1186/s12979-018-0141-8)

35 Campbell PG, Novak JF, Yanosick TB \& McMaster JH. Involvement of the plasmin system in dissociation of the insulin-like growth factor-binding protein complex. Endocrinology 1992130 1401-1412. (https://doi.org/10.1210/endo.130.3.1371448)

36 Schilbach K, Olsson DS, Boguszewski MCS, Bidlingmaier M, Johannsson G \& Jørgensen JOL. Biomarkers of GH action in children and adults. Growth Hormone \& IGF Research 201840 1-8. (https://doi. org/10.1016/j.ghir.2018.03.005)

Received in final form 7 May 2019

Accepted 10 May 2019
This work is licensed under a Creative Commons Attribution-NonCommercial 4.0 International License. ded from Bioscientifica.com at 04/26/2023 02:46:01AM 